\title{
Pharmacognostical and Preliminary Phytochemical Investigations on fruit of Vaccinium macrocarpon aiton
}

\author{
Manisha Khaneja', Sumeet Gupta*1 and Anupam Sharma² \\ 'Department of Pharmacology, M. M. College of Pharmacy, M. M. University, Mullana, (Ambala), Haryana, India. \\ 2University Institute of Pharmaceutical Sciences, Panjab University, Chandigarh, India.
}

\begin{abstract}
Background: Vaccinium species are hostile nutraceutical fruit in India as well as all over the world. In recent years, Vaccinium macrocarpon Aiton is used as a functional food for treating various diseases without authentication. Objective: The current work was investigated to perform the morphoanatomical and physicochemical of Vaccinium macrocarpon Aiton fruit. Method: Pharmacognostic studies were carried out for different parameters include organoleptic, macroscopic, microscopic, fluorescence and physicochemical analysis. Results: The fruit was shining burgundy purple in colour having smooth lustrous surface, globular to ellipsoidal in shape with $10-15 \mathrm{~mm}$ in length and diameter was $9 \mathrm{~mm}$. The main microscopic characteristic of fruit showed ovules, compact angular parenchyma cells, developed sclerenchymatous outer sheath, central xylem and phloem strands. Fruit powder showed oil bodies, spherical parenchyma cells in large thick masses and walls of the epicarp demonstrated cellulose content. Further, physicochemical examination of fruit powder showed loss on drying, total ash, insoluble ash as $9.23,7.8$, and $9.16 \% \mathrm{w} / \mathrm{w}$ respectively. The water and alcohol soluble extractives values of the fruit were 24.74 and $76.88 \%$ respectively. Anthocyanins and flavonids were also confirmed by phytochemical screening. Conclusion: $A$ variety of pharmacognostic features was found in fruitful way which may help in identification and standardization of Vaccinium macrocarpon Aiton fruit in a crude form.
\end{abstract}

Key words: Fruit, Morphoanataomical, Microscopy, Physicochemical analysis, Vaccinium macrocarpon aiton.

\section{SUMMARY}

- Vaccinium macrocarpon Aiton is a Nutraceutical food having potential pharmacological properties for the treatment of various disorders. It is also known as cranberry fruit.

- A fruit is having different types of flavonoids and isoflavonids. The main constituents are anthocyanins and quercetin category.

- Our study of this fruits shows phytochemical and pharmacognostical results and it is having great importance in its field.

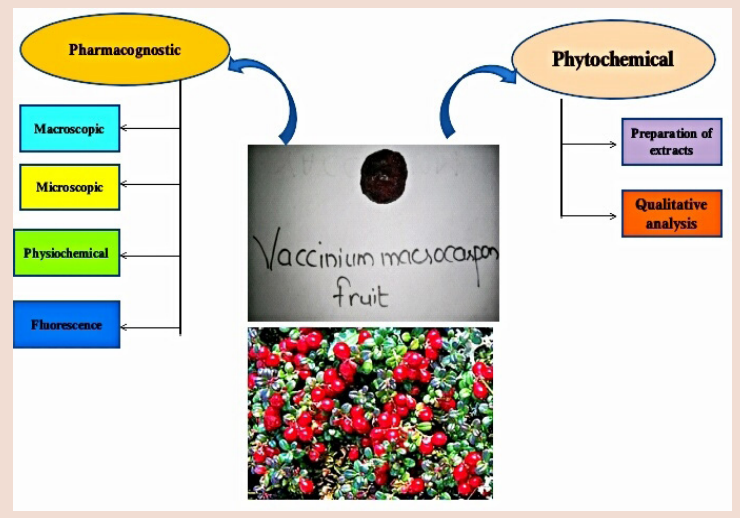

PICTORIAL ABSTRACT

Abbreviations used: TBA: Tertiary butyl alcohol, $\mu \mathrm{m}$ : micro meter, gm: gram, h: hour, mm: milli meter, CVS: Carpellary vascular strand, Ep: Epidermis, MC: Mesocarp, Ph: Pholem, Se: Septa, SE: Sub epidermal layer, X: Xylem, OB: Oil body, PC: Parenchyma cells, Pc: Pericarp, CC: Carpellary chamber, VS: Vascular strand.

Correspondence:

Dr. Sumeet Gupta, Professor, Department of Pharmacy, M. M. College of Pharmacy, M. M. University, Mullana, (Ambala), Haryana, India.

Phone no: +91 9872620252; Fax no: +918059930156

Email: sumeetgupta25@gmail.com

DOI : $10.5530 /$ pj.2015.6.3

\section{INTRODUCTION}

Ericaceae or heath family is the largest family in Ericales containing 128 genera and 4,000 species all over the world. Still many new species are being discovered. Numerous member of ericaceae are important in horticulture (e.g., rhododendrons, azaleas) or in small fruit crops (cranberries, blueberries). ${ }^{1}$ Vaccinium (Ericaceae) is a genus of around 450 species of deciduous, evergreen dwarf, prostrate, or erect shrubs, vines, and trees includes a wide range of edible berries such as cranberry, blueberries, tackleberries, hurtleberries, huckleberries, farkle berries, sparkleberries, deer berries, and southern gooseberries. ${ }^{2}$ There are many subgenera and several sections such as subgenus Oxycoccus (Section Oxycoccus), subgenus Vaccinium (Section Batodendron, Brachyceratium, Bracteata, Ciliata, Cinctosandra, Conchophyllum, Cyanococcus, Eococcus, Epigynium, Hemimyrtillus, Myrtillus, Neurodesia, Oarianthe, Oreades, Pachyanthum, Polycodium, Pyxothamnus, Vaccinium, Vitis-idaea).

Berry fruit belongs to vaccinium species are used as a medicinal food across the world. Very few species are available in India like Vaccinium neilgherrense Wt, Vaccinium myrtillus and Vaccinium leschenaultia wt.
An American cranberry Vaccinium macrocarpon Aiton which is generally known as "large cranberry" having diploid in nature present in various part of the geographical regions like Northeastern USA, British Columbia, Europe, North America, Central America, Central and South East Africa, Madagascar, Japan and Asia. Cranberries have their own important role as a traditional health improve agent and produced in the form of fruit, concentrated juices, jams, chocolates, candy's, sauces and spray-dried powders. ${ }^{3}$

Now days, a large cranberry ( $V$. macrocarpon) is one of the considerable nutraceutical source in functional foods industry. It is best known for the treatment and prevention of urinary tract infections (UTIs) from last many years. Cranberries and cranberry constituents have also been shown to possess antibacterial, ${ }^{4-5}$ anti-viral, ${ }^{6}$ anti-mutagenic, ${ }^{7}$ anticarcinogenic, ${ }^{8}$ anti-tumorigenic, ${ }^{9}$ anti-angiogenic ${ }^{10}$ and antioxidant activities. ${ }^{11}$ Several common chemical constituents are present among all vaccinium species which possess pharmacological properties. Cranberries contain a high amount of phenolic acid such as benzoic acid, hy- 
droxycinnamic acid p-coumaric, sinapic, caffeic and ferulic acid. The predominant flavonoids are flavonols, flavan-3-ols (particularly proanthocyanidins). ${ }^{12}$ The six major anthocyanins are peonidin-3-galactoside, cyanidin-3-galactoside, cyaniding-3-arabinoside, peonidin-3-arabinoside, peonidin-3-glucoside and cyaniding-3-glucoside. ${ }^{13-15}$ A review of literature revealed that no pharmacognostic standards have been recorded for this nutraceutical drug. Hence the present investigation was undertaken to evaluate various pharmacognostical standards like macroscopic and microscopy of fruits and its powder; physiochemical values and preliminary analysis of Vaccinium macrocarpon fruits so that authentic plant material could be explored for its therapeutic claim.

\section{MATERIAL AND METHODS}

\section{Procurement of plant materials}

Vaccinium macrocarpon, fruits were purchased from Shaanxi Nigbo Extracts Company Ltd, China, during December 2011. The fruits were authenticated with vide batch number CB091012 from the company. The fresh fruits material was cleaned with distilled water to remove debris and dried at $35-40^{\circ} \mathrm{C}$ for 10 days and, pulverized in the electric grinder and the powder was passed through sieve no. 60 and stored in airtight container for further extraction.

\section{Chemicals and instruments}

All the chemicals used in the study were of analytical grade and were obtained from Rankem limited India and Nice chemicals. Compound microscope, glass slides, cover slips, watch glass and other common glass ware were the basic apparatus and instruments used for the study. Microphotographs were taken using a motic images microscope.

\section{Anatomical evaluation}

Anatomy provides one to discover convincing diagnostic characters for a specific plant species (of crucial importance in quality control), and it also allows one to observe the distribution of compounds in the plant matrix.

\section{Macroscopic study}

Various organoleptic features and morphological characters of Vaccinium macrocarpon fruit like color, shape, size, odour, taste and fracture were evaluated.

\section{Microscopic study}

For microscopic evaluation, fruits were cut and fixed in chemical (Formalin $5 \mathrm{ml}+$ acetic acid $5 \mathrm{ml}+70 \%$ ethyl alcohol-90 ml). After $24 \mathrm{hrs}$ of fixing, the specimens were dehydrated with graded series of tertiarybutyl alcohol (TBA) as per the procedure of Sass, $1940 .{ }^{16}$ Infiltration of the specimens was carried by gradual addition of paraffin wax (melting point 58-60 C) until TBA solution attained super saturation. The specimens were cast into paraffin blocks. The paraffin embedded specimens were sectioned with the help of rotary microtome. The thickness of the sections was 10-12 $\mu \mathrm{m}$. Dewaxing of the sections was by customary procedure. ${ }^{17}$ The characteristic structures and cell components were observed and their photographs were taken using photomicrography.

\section{Physiochemical analysis}

In this study, dried fruit material was used for quantitative determination of physiochemical values like loss on drying, total ash, acid insoluble ash, water soluble ash, sulphated ash values and extractive values were determined as per reported method. ${ }^{18}$

\section{Fluorescence analysis}

Fluorescence study of fruit powder was performed as per reported standard procedure. ${ }^{19}$ A small quantity of the fruit powder was placed on a grease free clean microscopic slide and 1-2 drops of the freshly prepared reagent solution were added, mixed by gently tilting the slide and waited for 1-2 min. then the slide was placed inside the UV chamber and observed in visible light, short $(254 \mathrm{~nm})$ and long $(365 \mathrm{~nm})$ ultraviolet radiations. The colours observed by application of different reagents in different radiations were recorded.

\section{Preparation of extracts}

Fruit powder material (10 gm) was macerated by exhaustive method for preparation of three different extracts using acetone water (70:30), Ethanol and water (40: 60) with inorganic salt (2.5 gm) and methanol, water and ethyl acetate (80:19.5:0.5), Each combination were used for $72 \mathrm{~h}$ then $48 \mathrm{~h}$ and lastly $24 \mathrm{~h}$. the last trace solvents was removed by vacuum drying method. Yields were calculated on the basis of percentage w/w. The extracts were stored below $4^{\circ} \mathrm{C}$ until further used. The extracts were concentrated by performing the qualitative chemical tests to determine various chemical constituents and investigated fluorescence analysis. ${ }^{20}$

\section{RESULTS}

\section{Macroscopic study of fruit}

Morphological evaluation (Figure 1) of the fruit showed shines burgundy purple in colour. The shape was globular to ellipsoidal and the size about $10-15 \mathrm{~mm}$ in length and having diameter $9 \mathrm{~mm}$. This fruits possess smooth lustrous surface showed characteristics in odor and sweet taste.

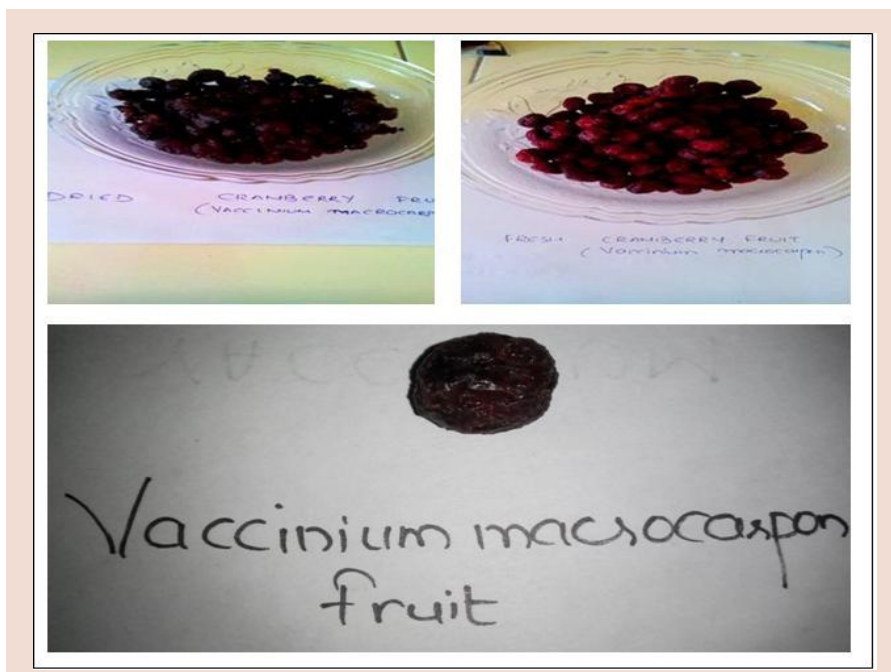

Figure 1: Fruits of Vaccinium macrocarpon

\section{Microscopic study of fruit}

Transverse section of fruit demonstrated spherical, fleshy berry with 14 $\mathrm{mm}$ thickness. It is tetra carpellary with many ovules on axile placentation. The fruit consists of thin layers of epidermis with prominent cuticle and a few layers of compact angular parenchyma cells. This portion represents the epicarp of fruit. The remaining portion of the fruit is thick a parenchymatous which represents the mesocarp of the fruit. The mesocarp includes several layers of wide parenchyma cells with wavy thin cell walls. There are small circular vascular strands distributed in the mesophyll tissue (Figure 2a and $2 \mathrm{~b}$ ). The vascular strands of the pericarp are circular with well developed sclerenchymatous outer sheath and central xylem and phloem strands (Figure 2c). The fruit is divided into 4 carpels by thick wavy septa (Figure 3a and 3b). The septa are thick and consist of epidermal layers and inner parenchymatous tissue. In the centre of the union of the 4 septa there are four circular vascular strands. These vascular strands are called carpellary vascular strands. In the pericarp, the 


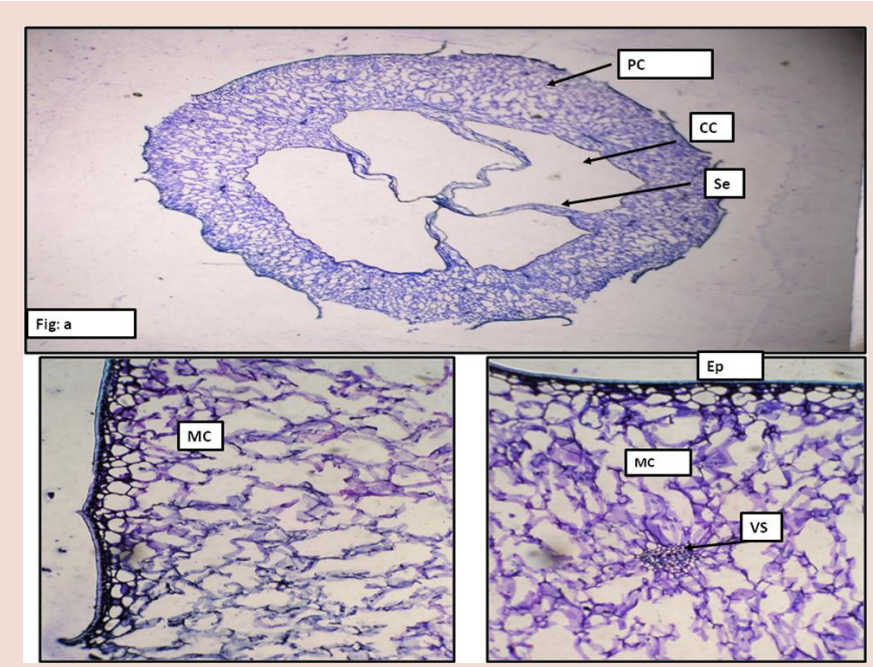

Figure 2: a) Transverse section of fruit entire view b) Epicarp and outer carp mesocarp of the fruit c) Mesocarp with circular vascular bundle (CC: Carpellary chamber, EP: Epidermis, MC: Mesocarp, Se: Septa, Pc: Pericarp, VS: Vascular strand)

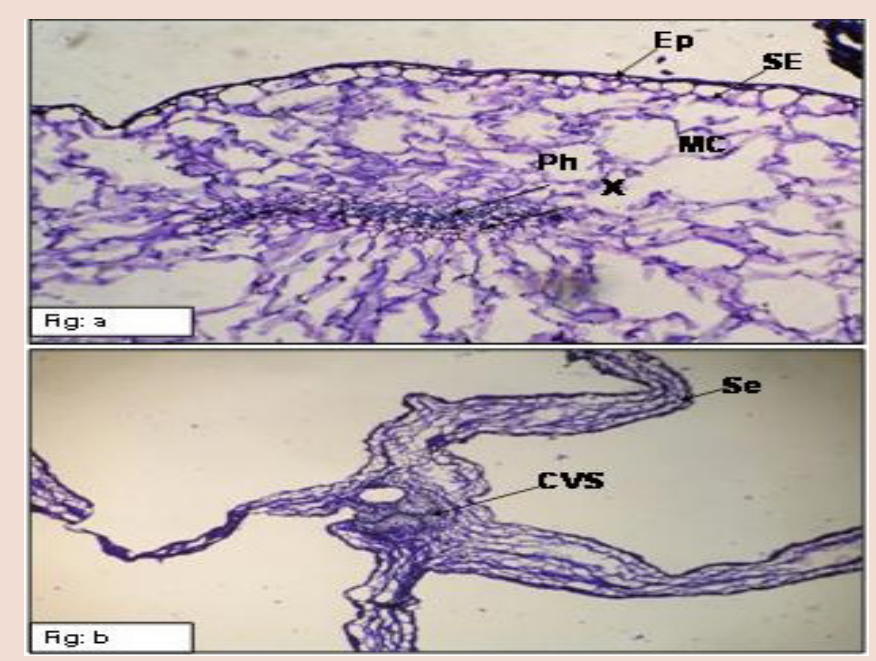

Figure 4: a) Transverse section of pericarp of the fruit showing a flat vascular strand b) Central part of the septa showing of circularly carpellary vascular strands

(CVS: Carpellary vascular strand, Ep: Epidermis, MC: Mesocarp, Ph: Pholem, Se: Septa, SE: sub epidermal layer, X: xylem)

vascular strands may be flat (Figure 4a) or circular (Figure 4 b). The flat vascular strands have a transverse row of xylem elements with phloem located on the outer part of the xylem strand (Figure $4 \mathrm{a}$ ). The pericarp of the fruit is $350 \mu \mathrm{m}$ thick.

\section{Powder microscopy}

The powder of the fruit showed oil bodies which was variable in shape and size. They were found floating appeared brown in color and stained with neutral red (Figure 5a). With addition to this, it showed spherical parenchyma cells in large thick masses (Figure 5a) or small group of 2 or 3 cells composed of oil bodies which stain dark brown (Figure 5b). On the surface, small pieces of epicarp were seen in surface view. These pieces consist of polyhedral thick walled parenchyma cells (Figure 6a and $6 \mathrm{~b}$ ). The walls of the epicarp have cellulose content and the cells have wide empty lumen.

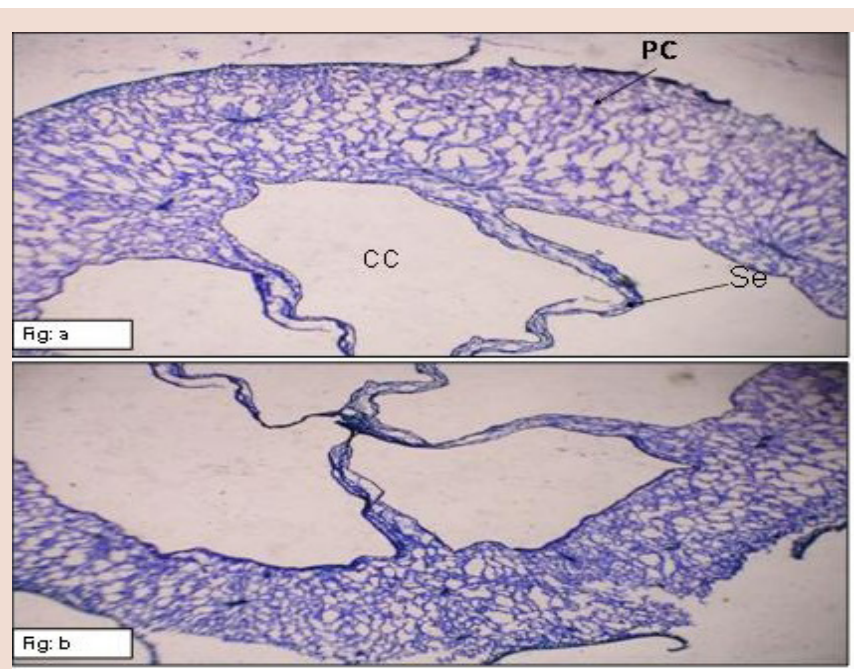

Figure 3: a) and b) Transverse section of fruit showing two halves of the fruit (CC: Carpellary chamber, Pc: Pericarp, Se: Septa)

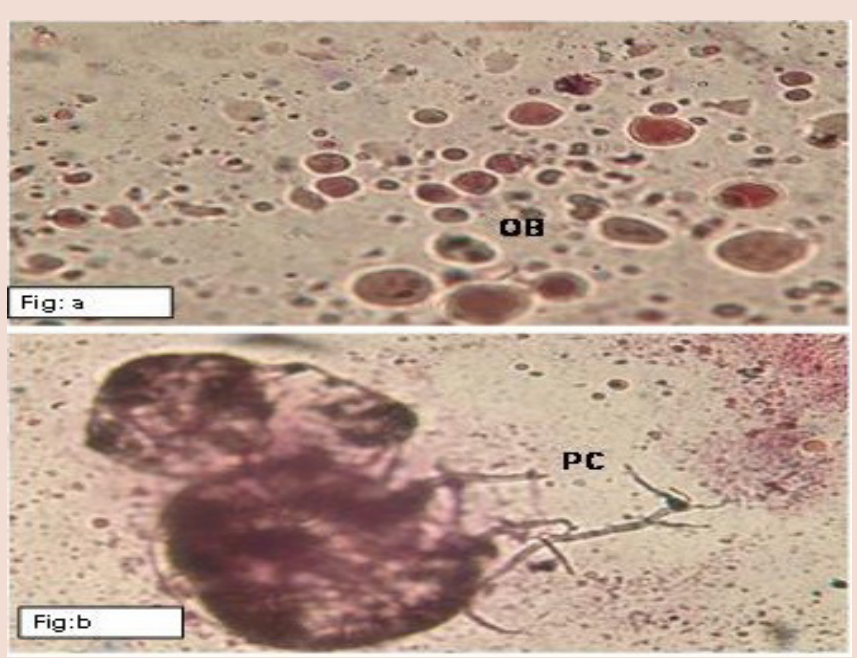

Figure 5: a) Fruit powder showing droplets of oil bodies b) Parenchyma cells of the pericarp showing cell inclusions

(OB: Oil body, PC: Parenchyma cells)

\section{Fluorescence analysis}

The Fluorescence characteristics of the fruit powder with different chemical reagents and fruit extracts are summarized in Table 1 and Table 2.

\section{Physicochemical Parameters}

In this study, various physicochemical parameters like loss on drying, total ash, acid insoluble ash, water soluble ash, sulphated ash and extractives values were determined in triplicate as mentioned in Table 3. The total yield and morphological characteristics of extract was shown in Table 4.

The qualitative results (Table 5) of all three extracts of Vaccinium macrocarpon fruit showed the presence of carbohydrates, flavonoids and anthocyanins, while these extracts could not show any positive indication for proteins, amino acids and alkaloids. The presence of flavonoids and 


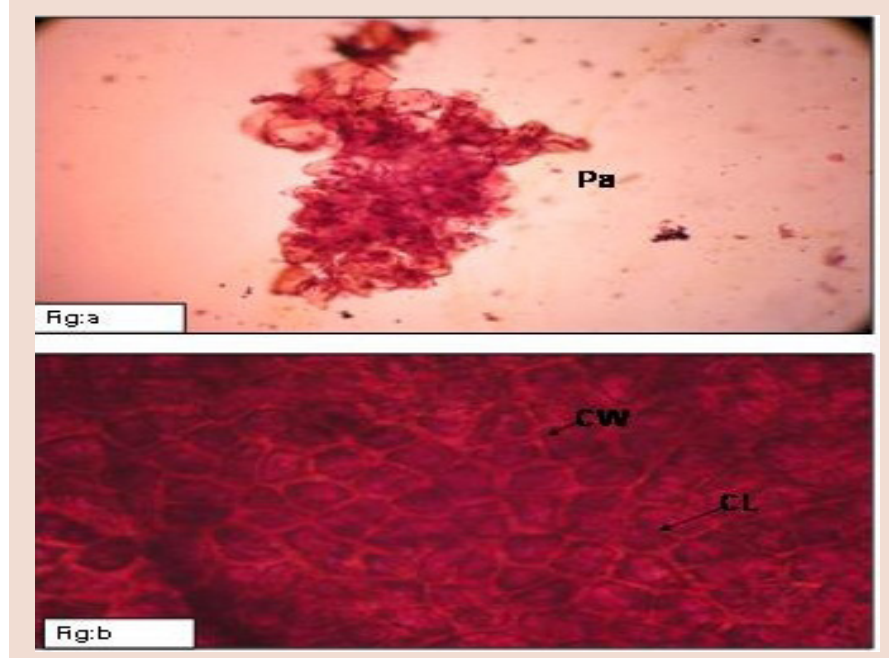

Figure 6: a) A thick mass of mesocarp parenchyma cells b) Surface view of the epicarp (epidermis of the fruit

(Cw: Cell wall, Pa: Parenchyma)

Table 1: Fluorescence analysis of VacciniuWm macrocarpon fruit powder

\begin{tabular}{cccc} 
& \multicolumn{2}{c}{ Under UV light } & \\
\cline { 2 - 3 } Treatment & $\begin{array}{c}\text { Short wavelength }(254 \\
\mathrm{nm})\end{array}$ & $\begin{array}{c}\text { Long wavelength }(365 \\
\mathrm{nm})\end{array}$ & Visible light \\
\hline Powder as such & Dark Brown & Brownish Black & Blackish Brown \\
Powder $+\mathbf{5} \% \mathrm{NaOH}$ & Cherry Brown & Brownish Black & Brown \\
Powder $+\mathbf{5 \% ~ K O H}$ & Cherry Brown & Dark Black & Cherry Brown \\
Powder $+\mathbf{5} \% \mathrm{FeCl}_{3}$ & Cherry Brown & Brownish Black & Cherry Brown \\
Powder + conc $\mathrm{H}_{2} \mathrm{SO}_{4}$ & Dark Black & Reddish Black & Brownish Black \\
Powder + conc $\mathrm{HCl}$ & Greenish Brown & Blackish Brown & Brownish Black \\
Powder + conc $\mathrm{HNO}_{3}$ & Greenish & Reddish Black & Yellowish Brown \\
\hline
\end{tabular}

Table 2: Fluorescence nature of various extracts of Vaccinium macrocarpon fruit powder

\begin{tabular}{|c|c|c|c|}
\hline \multirow{2}{*}{ Treatment } & \multicolumn{2}{|c|}{ Under UV light } & \multirow{2}{*}{ Visible light } \\
\hline & Short wavelength $(254 \mathrm{~nm})$ & Long wavelength $(365 \mathrm{~nm})$ & \\
\hline Acetone-Water (70:30) & Yellowish Black & Dull Brown & Yellowish Black \\
\hline $\begin{array}{c}\text { Ethanol + Inorganic salt + Water } \\
(40: 60)\end{array}$ & Yellowish Black & Black & Brownish Black \\
\hline $\begin{array}{c}\text { Methanol + Ethyl Acetate + Water } \\
(80: 0.5: 19.5)\end{array}$ & Brown & Blackish Brown & Brownish Black \\
\hline
\end{tabular}

Table 3: Physicochemical analysis of Vaccinium macrocarpon fruit

\begin{tabular}{cc|}
\hline Parameters & $\begin{array}{c}\text { Value obtained on dry weight basis } \\
(\% \mathrm{w} / \mathrm{w})\end{array}$ \\
\hline Loss on Drying & $9.236 \pm 33.09$ \\
Water soluble extractives & $76.88 \pm 5.19$ \\
Alcohol soluble extractives & $24.74 \pm 4.22$ \\
Total ash & $7.8 \pm 12.07$ \\
Acid Insoluble ash & $9.1666 \pm 11.33$ \\
Foreign matter & Nil \\
\hline
\end{tabular}

anthocyanins was also confirmed by TLC method which showed pinkish violet colour having $\mathrm{R}_{\mathrm{f}}$ values, which was found in the range of $0.15-0.95$ (data not shown).

\section{DISCUSSION}

Ethno medicinally, the fruit of this plant has been use by many people in the treatment of various diseases especially in cancer and ulcers without knowing any pharmacognostical authentication. The pharmacognostical standardization of a crude drug is an important tool for identifying any morphological and physicochemical characters and it is helpful to add in different pharmacopeias. Two methodologies has been used for evaluating pharmacognostic parameters one is microscopic and another is macroscopic. Till now, no pharmacognostic work has been done on this medicinally potent plant fruit. The present work was undertaken to lay down the standards which could be useful for establishing authenticity. The macroscopic characters of fruit served as diagnostic parameters which possess fractured surfaces of fresh and dried fruit, typically tongue sensitizing aromatic taste and odour. Ash and extractive values are also 
Table 4: Morphological characteristics and percentage yield of Vaccinium macrocarpon fruit extract

\begin{tabular}{|c|c|c|c|c|c|}
\hline Extract & $\%$ dry wt (mg) & Colour & Odour & Consistency & $\%$ Yield \\
\hline $\begin{array}{c}\text { Acetone-Water } \\
(70: 30)\end{array}$ & 154.15 & Brownish Black & Odourless & Semi-solid viscous & 15.41 \\
\hline $\begin{array}{l}\text { Ethanol+ Inorganic } \\
\text { salt + Water }(40: 60)\end{array}$ & 174.4 & Brownish Black & Odourless & Semi-solid viscous & 17.44 \\
\hline $\begin{array}{c}\text { Methanol + Ethyl } \\
\text { Acetate + Water } \\
(80: 0.5: 19.5)\end{array}$ & 70.45 & Brownish Black & Odourless & Semi-solid viscous & 7.045 \\
\hline
\end{tabular}

Table 5: Phytochemical test of vaccinium macrocarpon fruit

\begin{tabular}{|c|c|c|c|c|}
\hline \multirow[b]{2}{*}{ Constituents } & \multirow[b]{2}{*}{ Phytochemical test } & \multicolumn{3}{|c|}{ Extracts } \\
\hline & & Acetone-water $(70: 30)$ & $\begin{array}{l}\text { Ethanol+ Inorganic salt } \\
+ \text { + Water }(40: 60)\end{array}$ & $\begin{array}{c}\text { Methanol + Ethyl } \\
\text { Acetate + Water } \\
(80: 0.5: 19.5)\end{array}$ \\
\hline \multirow{3}{*}{ Carbohydrates } & a. Molisch test & ++ & ++ & ++ \\
\hline & b. Benedict test & ++ & ++ & ++ \\
\hline & c. Fehling test & ++ & ++ & ++ \\
\hline \multirow{2}{*}{ Proteins } & a. Biuret test & -- & -- & -- \\
\hline & b. Millon's test & -- & -- & -- \\
\hline \multirow{2}{*}{ Amino-Acids } & a. Ninhydrin test & -- & -- & -- \\
\hline & & -- & -- & -- \\
\hline \multirow{3}{*}{ Flavonoids } & a. Sulphuric acid & ++ & ++ & ++ \\
\hline & b. Lead acetate & ++ & ++ & ++ \\
\hline & c. Ferric Chloride & & & \\
\hline \multirow{3}{*}{ Alkaloids } & a. Dragendroff & -- & -- & -- \\
\hline & b. Mayer test & -- & -- & -- \\
\hline & c. Wagner test & -- & -- & -- \\
\hline \multirow{2}{*}{ Anthocyanins } & a. Sodium Hydroxide & ++ & ++ & ++ \\
\hline & b. $\mathrm{KMnO}_{4}$ Discoloration & & & \\
\hline
\end{tabular}

reliable aid for detecting adulteration. Ash values are use to give an idea about inorganic composition and other impurities present in drug and extractive values shows the chemical constituents present in the crude drug and also helpful in estimation of specific constituents which are soluble in particular solvents. The fluorescent analysis under day light and UV light by treatment with different chemical reagents showed different color which suggested the presence of active chemical constituents. As per phytochemical screening, the fruit of Vaccinium macrocarpon showed mainly anthocyanins and flavonoids which was also reported in previous study. ${ }^{21-22}$

As per our results, water soluble extractive value indicated the presence of sugar and inorganic compounds where as alcohol soluble extractive value indicated the presence of polar constituents such as glycosides, anthocyanins and flavonoids similar results were also reported by previous researcher. $^{23}$

\section{CONCLUSION}

From these parameters, the results are being useful for setting up some diagnostic indices for identification and preparation of monograph according to pharmacopeia. Other related species can also be compared from these parameters and thus would helpful in opening up of new avenues in the use of natural products for therapeutic purposes. Some of the manufacturers can also utilize these data for preparation of formulation according to their needs. Many therapeutics like anti diabetic, anti obesity and anti hypertensive activity are still lacking of this plant, for future pharmacological study, these data can be useful for collection and identification of this plant.

\section{ACKNOWLEDGEMENTS}

The authors are grateful to management for offering the requisite technical help to accomplish this study. The authors acknowledge the excellent technical work under Plant Anatomy Research Centre, Chennai providing the histopathology microscopy facility. The authors gratefully acknowledge the colleagues for encouraging and providing the necessary research facilities to conduct this study.

\section{CONFLICT OF INTEREST}

Authors declare no conflict of interest.

\section{FUNDING}

Not received any funding from any sources.

\section{REFERENCES}

1. Steven PMCL. The ericales: an expanding order herbarium. Department of Plants science, University of Arizona; 1-12.

2. Brown PN, Turi CE, Shipley PR, Murch SJ. Comparison of large (Vaccinium macrocarpon Ait.) and small Vaccinium oxycoccus L. Vaccinium vitis-idaea L) Cranberry in vritish columbia by Phytochemical determination, Antioxidant potential and Metabolomic propiling with Chrometric analysis. Plany medica. 2012; 78(6): 630-40. 
3. Mc kay DL, Blumbers JB. Cranberries Vaccinium macrocarpon and cardiovascular diseases risk factors. Nutr. Reviw. 2007; 65(11): 490-502.

4. Cavanagh HM, Hipwell M, Wilkinson JM. Antibacterial activity of berry fruits used for culinary purposes. J Med Food. 2003; 6(1): 57-61.

5. Leitao DP, Polizello AC, Ito IY, Spadaro AC. Anti-bacterial screening of Anthocyanic and Proantho-cyanic fractions from cranberry juice. J Med Food. 2005; 8(1): 36-40.

6. Weiss El, Houri-Haddad Y, Greenbaum E, Hoch-man N, Ofek I, Zakay-Rones $Z$. Cranberry juice constituents affect influenza virus adhesion and infectivity. Antiviral Res. 2005; 66(1): 9-12.

7. Vattern DA, Jang HD, Levin R, Shetty K. Synergism of cranberry phenolics with eliagic acid and rosmarinic acid for antimutagenic and DNA protection functions. J Food Biochem. 2006; 30(1): 98-116.

8. Sun J, Liu RH. Cranberry phytochemical extracts induce cell cycle arrest and apoptosis in human MCF-7 breast cancer cells. Cancer Left 2006; 241(1): 124-34.

9. Seeram NP, Adams LS, Hardy ML, Heber D. Total cranberry extract versus its phytochemical constituents: Anti proliferative and synergistic effects against human tumor cell lines. J Agric Food Chem. 2004; 52(9): 2512-17.

10. Roy S, Khanna, Alessio HM, et al. Anti-angiogenic property of edible berries. Free Rad Res. 2002; 36(9): 1023-31.

11. Vinson JA, Su X, Zubik L, Bose P. Phenol antioxidant quantity and quality in foods: fruits. J Agric Food Chem. 2001; 49(11): 5315-21.

12. Zuo Y, Wang C, Zhan J. Separation, characterization, and quantitation of benzoic and phenolic antioxidants in American cranberry fruit by GC-MS. J Agric Food Chem. 2002; 50(13): 3789-94.

13. Cunningham DG, Vannozzi SA, Turk R, Roderick R, O'Shea E, Brilliant K. Cranberry phytochemicals and their health 5 benefits. In: Shahidi F, Weeras-inghe DK, ed. Nutraceutical Beverages: Chemistry, Nutrition, and
Health Effects, ACS Symposium Se-ries 871. Washington, DC: American Chemical Society; 2004. 35-51.

14. Hong V, Wrolstad RE. Use of HPLC separation/photodiode array detection for characterization of Anthocyanins. J Agric Food Chem. 1990; 38(3): 708.

15. Prior RL, Lazarus SA, Cao G, Muccitelli H, Ham-merstone JF. Identification of procyanidins and anthocyanins in blueberries and cranberries (Vaccinium spp.) using high-performance liquid chromatography/mass spectrometry. J Agric Food Chem. 2001; 49(3): 1270-6.

16. Sass JE. $1^{\text {st }}$ ed. New York: Mc Graw Hill Book and Co, Elements of botanical micro technique; 1940. 222.

17. Johnsen DA. Plant Micro technique. Mc Graw Hill Book Co. Inc. New York; 1940. 154.

18. Kulkarni YA, Gokhale SB, Yele SU, Surana SJ, Tatiya AU. Pharmacognostical studies and preliminary phytochemical investigations on the bark of persea macrantha (Nees) kosterm (Lauracea). Indian Journal of Natural Products and Resources 2011; 2(2): 211-7.

19. Kokashi CJ, Kokashi RJ, Sharma M. Fluorescence of powdered vegetable drugs in ultra-violet radiation. J Am Pharm Assoc. 1958; 47(1): 715-7.

20. Ramaan N. Phytochemical Techniques. New Indian Publishing Agency; 2006. 19

21. Wu X, Beecher GR, Holden JM, Haytowitz DB, Gebhardt SE, Prior RL. Concentrations of Anthocyanins in Common Foods in the United States and Estimation of Normal Consumption. Journal of Agricultural and Food Chemistry 2006; 54(11): 4069-75.

22. Fuleki T, Francis FJ. Quantitative methods for anthocyanins. I. Extraction and determination of total anthocyanin in Cran berries. Journal of Food Science 1968; 33(1):72-7.

23. Fuleki T, Francis FJ. Quantitative methods for anthocyanins. II. Determination of total anthocyanin and degradation index for Cranberry juice. Journal of Food Science 1968; 33(1): 78-83.

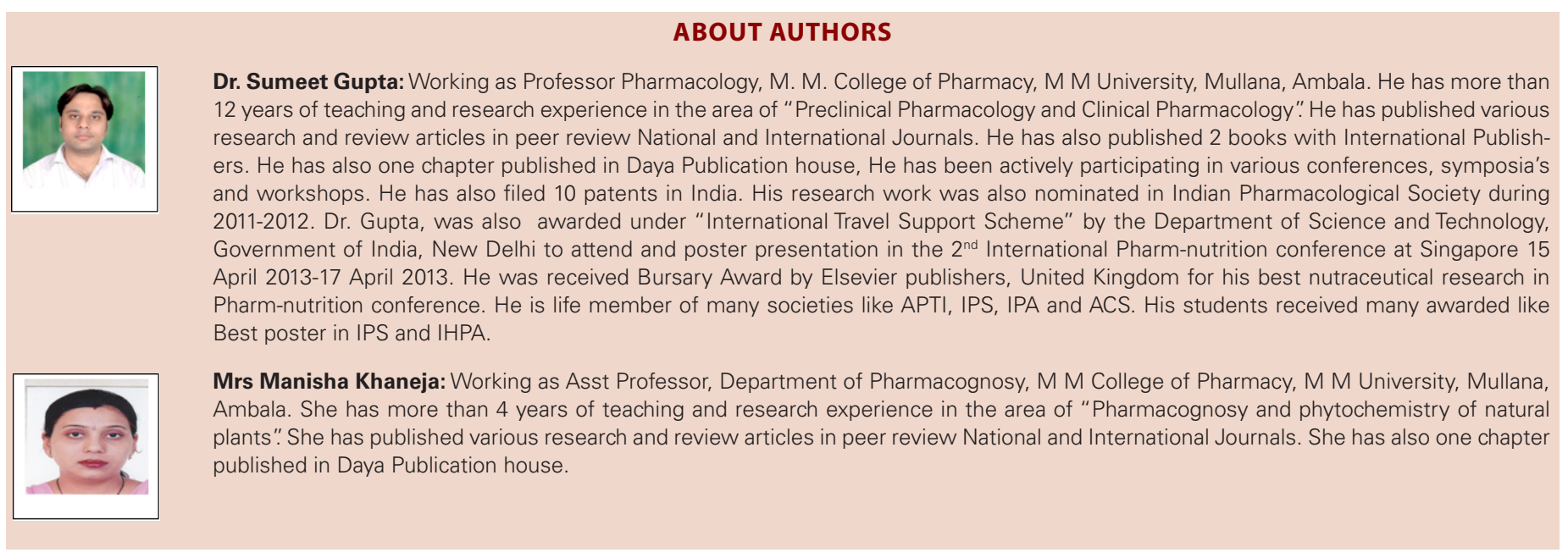

